Case Report

\title{
Small clonal B-cell population in the bone marrow as a possible tool in the diagnosis of occult primary parotid lymphoma
}

\section{Pequeña población de células B monoclonales en medula ósea como posible herramienta diagnóstica en el linfoma oculto primario de parótida}

\author{
Martha Romero ${ }^{1}$, Guido R González-Fontal ${ }^{2}$, Mónica Duarte ${ }^{3}$, Carlos Saavedra ${ }^{1}$, and Andrés F Henao-Martínez ${ }^{4}$ \\ ${ }^{1}$ Department of Pathology. Fundación Santa Fe de Bogotá, Bogotá, Colombia. \\ ${ }^{2}$ Division of Hemato-Oncology. Clínica Rey David, Cali, Colombia. \\ ${ }^{3}$ Hematology. Fundación Santa Fe de Bogotá, Bogotá, Colombia. \\ ${ }^{4}$ Division of Infectious Diseases, University of Colorado Denver, USA.
}

Romero M, González-Fontal GR, Duarte M, Saavedra C, and Henao-Martínez AF. Small clonal B-cell population in the bone marrow as a possible tool in the diagnosis of occult primary parotid lymphoma. Colomb Med (Cali). 2016; 47(1):59-62.

(C) 2016. Universidad del Valle. This is an Open Access article distributed under the terms of the Creative Commons Attribution License, which permits unrestricted use, distribution, and reproduction in any medium, provided the original author and source are credited.
Article history:
Abstract
Resumen

Received: 18 December 2014 Case Description: An 82-years old Hispanic woman with a past Descripción de caso: Mujer hispana de 82 años con una Revised: 17 November 2015 medical history significant for pulmonary thromboembolism on oral historia médica significativa de tromboembolismo pulmonar en Accepted: 11 December 2015 anticoagulation, rheumatoid arthritis, and hypertension developed a anticoagulación, artritis reumatoide e hipertensión, la cual desarrolló

Keywords:

B-lymphocytes, bone marrow, diagnosis,

lymphoma, parotid gland

Palabras clave:

Linfocitos B, médula ósea, diagnóstico, linfoma, glándula parótida new onset thrombocytopenia. recientemente una trombocitopenia

Clinical Findings: Small clonal B-cells populations (SCBP) also Hallazgos clínicos: Una pequeña población de células B monoclonales known as monoclonal B-cell lymphocytosis was found as part of también conocida como linfocitosis monoclonal de células B fue the workup for an idiopathic thrombocytopenia and lead ultimately encontrado dentro del estudio de una trombocitopenia idiopática que to the diagnosis of parotid primary follicular lymphoma coexisting conllevó al diagnóstico de un linfoma folicular primario de parótida with Warthin tumor involving the bone marrow in a small extent and coexistiendo con un tumor de Warthin y un papiloma oncocítico oncocytic papilloma located in the maxillary sinus.

localizado en el seno maxilar.

Treatment and Outcome: Patient was treated with Rituximab Tratamiento y resultado: La paciente fue tratada con monoterapia de monotherapy with improvement on her platelet count.

Rituximab con una mejoría en su conteo de plaquetas.

Clinical relevance: Although it is unclear the role of this clonal cells, Relevancia clínica: Aunque el rol de las pequeñas poblaciones B they may work as a possible diagnostic tool for occult lymphomas. monoclonales no está completamente dilucidado, podrían tener Further prospective studies are needed to confirm this possible una aplicación como herramienta diagnóstica. Futuros estudios association. prospectivos son necesarios para confirmar esta posible asociación. 


\section{Introduction}

The small clonal B-cells populations (SCBP) have been studied widely in peripheral blood. These have been detected with an estimated frequency between $3.5 \%$ and $14.0 \%$ in healthy subjects older than 40 years ${ }^{1}$ and they are known as monoclonal B-cell lymphocytosis $(\mathrm{MBL})^{2}$. Its finding in peripheral blood is largely incidental, sometimes linked to some nonspecific clinical conditions $^{3,4}$ and in a minority of cases it confers an increased risk for the development of B-cell neoplasms ${ }^{5,6}$. Nevertheless, the clinical significance of detecting an SCBP in bone marrow as a primary finding is largely uncertain at this time. Its evaluation in bone marrow has been mainly used for lymphoma staging or to monitor response to treatment ${ }^{7}$. But, the role as a useful diagnostic tool and in the clinical management of patients with occult lymphoma is not known. We present an unusual case of SCBP detection of $1 \%$ in bone marrow by using a high sensitivity flow cytometry approach, during the evaluation of thrombocytopenia, which led to the diagnosis of a rare parotid follicular lymphoma associated with Warthin tumor which could not be found otherwise. The overall aim was to describe the possible association of SCBP with occult lymphomas.

\section{Case description}

An 82-years old Hispanic woman with a past medical history significant for pulmonary thromboembolism on oral anticoagulation, rheumatoid arthritis on treatment with hydroxychloroquine, and hypertension developed a new onset thrombocytopenia, with a platelet count of $52 \times 10^{9} / \mathrm{L}$ during a routine assessment. She denied any symptoms and her physical exam was unremarkable. Complete blood count showed a hemoglobin of $14.6 \mathrm{~g} / \mathrm{dL}$; and a white blood cells count, 5.9 x $10^{9} / \mathrm{L}$ with $71 \%$ segmented neutrophils, $17 \%$ lymphocytes (absolute lymphocyte count: $1.0 \times 10^{9} / \mathrm{L}$ ), 11\% monocytes, and $1 \%$ eosinophil. Her international normalized ratio was in a therapeutic range. Her initial thrombocytopenia evaluation based on the current guidelines ${ }^{8}$ did not reveal the presence of an alternative diagnosis. Infectious disease testing including human immunodeficiency virus (HIV) was negative. Hence, given her age, a bone marrow biopsy was performed.

Immunophenotypic studies of bone marrow cells, using 8-color flow cytometry approach (FACSCanto ll flow cytometer (BDB), and Infinicyt software program (Cytognos, V1.4)) detected $1 \%$ of Lambda-restricted B-cells CD $45^{+}, \mathrm{CD} 20^{+}$, CD10 ${ }^{+}, \mathrm{BCL}^{++}$(Fig. 1A-F), $\mathrm{FMC7}^{+}, \mathrm{CD}^{\mathrm{dim}}{ }^{\mathrm{d}}$, CD200 and CD5- (Fig. 1F). BM biopsy revealed a $1 \%$ paratrabecular small cleaved lymphocyte infiltrate. Immunohistochemical staining demonstrated CD20 (Fig. 1G-H), BCL2 and CD10 expression in tumor cells.

Assessment with positron emission tomography/computed tomography (PET/CT) showed two mass-like foci over right parotid (Fig. 2A-B) and left maxillary (Fig. 2C-D)

Parotid excisional biopsy multiparameter flow cytometry revealed a $42 \%$ of lambda-restricted B-cells, with low forward scatter and $\mathrm{SSC}, \mathrm{CD} 20^{+}, \mathrm{CD} 10^{+}, \mathrm{BCL}^{+}$(Fig. 2E), CD $38^{+}, \mathrm{CD} 19^{+}$, and $\mathrm{CD} 45^{+}$; consistent with a diagnosis of follicular lymphoma. Examinations of the histological sections confirmed a low-grade follicular lymphoma, with a $5 \%$ proliferation rate measured by Ki-67 (Fig. 2F-I). Translocation $\mathrm{t}(14 ; 18)$ (q32; q21) was detected in parotid lymphoma (Fig. 2J) as well as bone marrow biopsy, by using fluorescence in situ hybridization (IgH/ BCL2 dual color dual fusion translocation probes Vysis-Abbott).

The coexistence of a Warthin tumor composed of cystic spaces lined by papillary bilayered oncocytic epithelium was also observed (Fig. 2L-M). Pathologic examination of maxillary biopsy showed an oncocytic papilloma, constituted by a fibrovascular stroma lined by multiple layers of columnar cells with oncocytic features (Fig. 2N).

The final diagnosis was a parotid primary follicular lymphoma coexisting with Warthin tumor involving the bone marrow in a small extent and oncocytic papilloma located in the maxillary sinus. Given her age, performance status and intermediate risk FLIPI ( 2 points) she was treated with Rituximab monotherapy, having received four cycles at the last clinical follow-up with improvement on her platelet count up to $165 \times 10^{9} / \mathrm{L}$.

\section{Consent}

Written informed consent was obtained from the patient for publication of this case report and accompanying images.
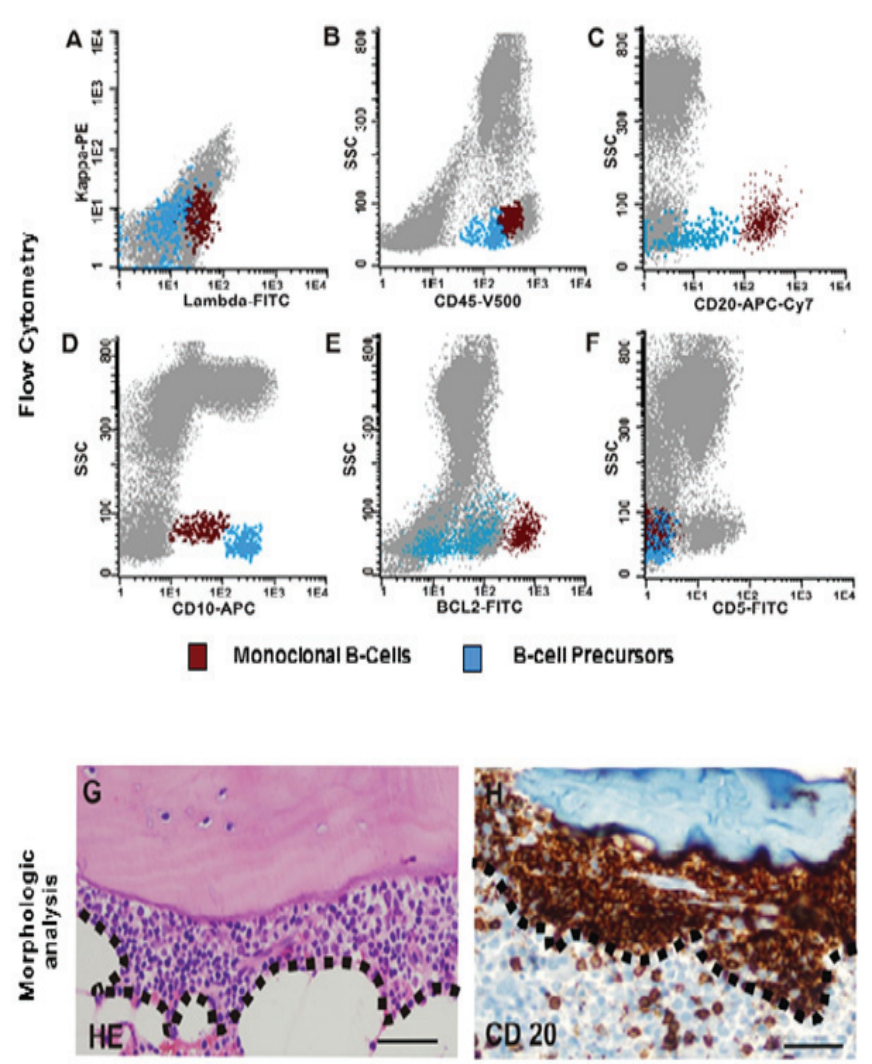

Figure 1. Bone marrow small clonal B-cells. Highly sensitive 8-color flow cytometry approach identified $1 \%$ of lambda-restricted B cells (A) CD45+, CD20+, CD10+, BCL2++, CD5- (B-F) (SSC:side-scattered light; red population: monoclonal B-cells; blue population: precursor Bcell with normal antigen expression) Morphologic analysis revealed a $1 \%$ abnormal paratrabecular small cleaved lymphocyte infiltrate $(G)$ (infiltration, surrounded by broken lines, HE: hematoxylin eosin staining). Immunohistochemistry staining demonstrated CD20 expression in paratrabecular tumor cells (original magnification for all photos x400 magnification, Bar= $50 \mu \mathrm{m})$. 

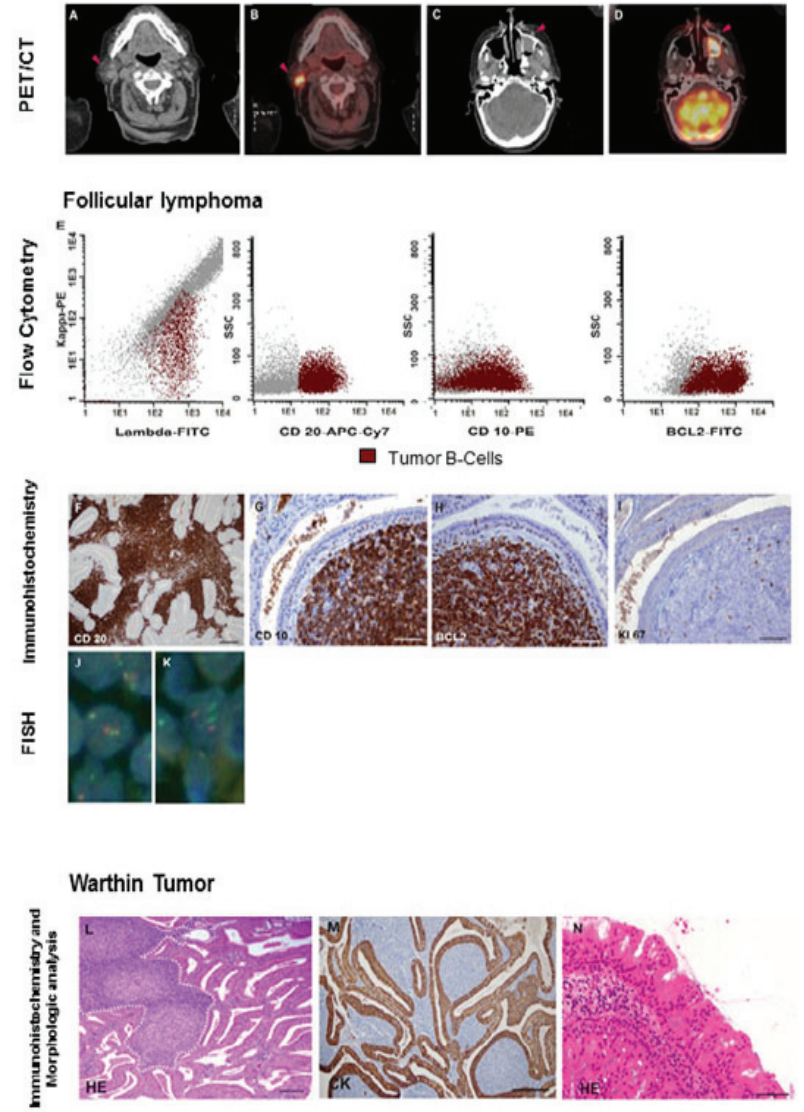

Figure 2. Coexistence of a parotid follicular lymphoma and Warthin tumor. PET/CT showed two mass-like foci (arrowheads on CT and fusion image) over right parotid (A-B) and left maxillary (C-D) with similar uptake. Parotid biopsy multiparameter flow cytometry showed lambda-restricted B-cells, CD20+, CD10+, BCL2+ (E). Histological analysis and immunochemistry confirmed a low-grade folicular lymphoma positive for CD20 (E, x200 magnification), CD10, BCL2, with low proliferation rate (G-H); I: Ki-67 immunostaining, (original magnification for all photos x400 magnification, Bar $=50 \mu \mathrm{m})$. Translocation (14; 18) was detected in bone marrow biopsy and parotid lymphoma by FISH (J: Dual-fusion pattern in a balanced $t(14 ; 18)(\mathrm{q} 32 ; \mathrm{q} 21)$ in parotid lymphoma cells). Normal signal pattern in epithelial cells is shown (K). Warthin Tumour composed of cystic spaces lined by oncocytic epithelium (L-M: follicular lymphoma: surrounded by broken white lines. CK: cytokeratin immunostaining) and oncocytic papilloma located over left maxillary $(\mathrm{N})$ were also confirmed (original magnification for all photos $\mathrm{x} 400$ magnification, Bar $=50 \mu \mathrm{m}$ ).

\section{Discussion}

The SCBP in peripheral blood behaves as a transient population, which might be associated with the normal process of immunosenescence in older people. It is also postulated that can be triggered by infectious agents that can cause chronic and persistent antigenic stimulation'. The majority of MBL (75\%) shows similar phenotypic characteristics to chronic lymphocytic leukemia cells and the remaining are classified as atypical lymphocytic leukemia and $\mathrm{CD} 5$-negative $\mathrm{MBL}^{10}$, and least frequent, $\mathrm{CD} 10+\mathrm{B}$-cell clones ${ }^{1}$.

The small clonal B-cells populations have been detected in myelodysplastic syndrome, post chemotherapy and benign disorders such as immune related or isolated thrombocytopenia, chronic obstructive pulmonary disease, and chronic cardiovascular disease ${ }^{11}$ and in $1 \%$ of cases will be precursor of B-cell neoplasm ${ }^{5,6}$. It is unclear if rheumatoid arthritis or its treatment played a role in the onset of the clonal cells or the tumor.

In the only available retrospective cohort review of patients with incidental documentation of SCBP detected in bone marrow; $29 \%$ of patients developed non-Hodgkin lymphoma ${ }^{11}$ in up to
40 months of follow up. Three patients were classified under the CD5-/CD10+ immunophenotype; from them, one developed non-Hodgkin lymphoma. Likewise, in the same study there were some limited associations with diffuse large B-cell lymphoma, hairy cell leukemia, splenic B-cell marginal zone lymphoma, and Waldenström macroglobulinemia. In our case, it led to the diagnosis of a rare parotid follicular lymphoma associated with Warthin tumor, an unusual coexistence, with 23 previous cases reported.

Herein we were able to establish an association of SCBP in bone marrow with a glandular based lymphoma. The finding of this type of population of cells prompted further workup that ultimately led to the final diagnosis. It is unclear the clinical significance of these clones and it still can be a serendipitous association; however they proved to be successful detecting varies forms of non-Hodgkin lymphoma, as pointed out in our case. Interestingly, in the previous report by Chen et al., what initially prompted further analysis in the majority of cases was cytopenias ${ }^{11}$. Similarly, the thrombocytopenia was the initially detected abnormality in this case. There is insufficient evidence to use these clone cells in BM as a potential screening tool for lymphomas or to consider them a real premalignant condition. Further prospective studies may prove useful to confirm the clinical utility of this particular finding.

Acknowledgment:

We specially thank Dr. Gonzalo Ucros and Dr. Bernal at the Division of Nuclear Medicine, Department of Radiology, Fundación Santa Fe Bogotá for their help reviewing and assembling PET/CT images and to Dr. Milton Lombana, Dr. Javier Segovia, and Dr. Li Wang for the critical review of the manuscript

\section{References}

1. Nieto WG, Teodosio C, Lopez A, Rodriguez-Caballero A, Romero A, Barcena P, et al. Non-CLL-like monoclonal B-cell lymphocytosis in the general population: prevalence and phenotypic/genetic characteristics. Cytometry B Clin Cytom. 2010; 78(Suppl 1): S24-34.

2. Marti GE, Rawstron AC, Ghia P, Hillmen P, Houlston RS, Kay N, et al. Diagnostic criteria for monoclonal B-cell lymphocytosis. Br J Haematol. 2005; 130(3): 325-32.

3. Wang C, Amato D, Fernandes B. CD5-negative phenotype of monoclonal B-lymphocytosis of undetermined significance (MLUS) Am J Hematol. 2002; 69(2): 147-9.

4. Vardi A, Dagklis A, Scarfo L, Jelinek D, Newton D, Bennett F, et al. Immunogenetics shows that not all MBL are equal: the larger the clone the more similar to CLL. Blood. 2013; 121(22):4521-8.

5. Shim YK, Vogt RF, Middleton D, Abbasi F, Slade B, Lee KY, et al. Prevalence and natural history of monoclonal and polyclonal B-cell lymphocytosis in a residential adult population. Cytometry B Clin Cytom. 2007; 72(5): 344-53.

6. Rawstron AC, Shanafelt T, Lanasa MC, Landgren O, Hanson C, Orfao A, et al. Different biology and clinical outcome according to the absolute numbers of clonal B-cells in monoclonal B-cell lymphocytosis (MBL) Cytometry B Clin Cytom. 2010; 78(Suppl 1): S19-S23. 
7. Cheson BD, Pfistner B, Juweid ME, Gascoyne RD, Specht L, Horning SJ, et al . Revised response criteria for malignant lymphoma. J Clin Oncol. 2007; 25(5): 579-86.

8. Neunert C, Lim W, Crowther M, Cohen A, Solberg L, Jr, Crowther MA, et al. The American Society of Hematology 2011 evidence-based practice guideline for immune thrombocytopenia. Blood.2011; 117(16): 4190-207.

9. Casabonne D, Almeida J, Nieto WG, Romero A, FernandezNavarro P, Rodriguez-Caballero A, et al. Common infectious agents and monoclonal B-cell lymphocytosis: a cross-sectional epidemiological study among healthy adults. PloS One. 2012; 7(12): e52808.
10. Fazi C, Scarfo L, Pecciarini L, Cottini F, Dagklis A, Janus A, et al. General population low-count CLL-like MBL persists over time without clinical progression, although carrying the same cytogenetic abnormalities of CLL. Blood. 2011; 118(25): 6618-25.

11. Chen W, Asplund SL, McKenna RW, Kroft SH. Characterization of incidentally identified minute clonal B-lymphocyte populations in peripheral blood and bone marrow. Am J Clinical Pathol. 2004; 122(4): 588-95. 